сударственной педагогической академии. 2014. № 18. C. $63-67$.

14. Софронов В.Ю. К вопросу о периодизации истории Русской православной церкви в Сибири // Урал и Сибирь в контексте развития российской государственности: мат-лы всерос. науч. конф. Курган: Изд-во КГУ, 2012. С. 103-105.

15. Государственный архив Алтайского края. Ф. 164. Оп. 1. Д. 5.

16. Дамешек Л.М., Дамешек И.Л. Сибирь в системе имперского регионализма (1822-1917 гг.). Иркутск: Оттиск, 2018. 416 с.

17. Любичанковский С.В., Камзина А.Д. Миссионерская деятельность Русской православной церкви как механизм имперской политики аккультурации. Оренбург: ОГАУ, 2017. 220 с.

18. Шевкун П.В. Православная церковь в коммуникативных процессах конца XVIII - первой поло- вины XIX в. // Вопросы истории. 2016. № 6. С. 141150.

19. Кимеев В.М., Копытов А.И. Горная Шория: история и современность. Историко-этнографические очерки. Кемерово: Примула, 2018. 600 с.

20. Государственный архив Томской области (ГАТО). Ф. 3. Оп. 12. Д. 688.

21. Потанин Г.Н. Среднеазиатский мессианизм // Сибирская жизнь. 1904. 18 июля. С. 2-4.

22. White J.M. Burkhanism, Toleration and the Russian Orthodox Church in the Altai (1904-1914) // Религиоведение. 2014. № 7. С. 21-30.

23. ГАТО. Ф. 10. ОП. 11. Д. 15.

24. Соколов К., Постников В. Известия с Алтая // Православный благовестник. 1907. № 2. С. 72-83.

25. Иннокентий, епископ. Алтайская миссия за 1908 г. // Православный благовестник. 1909.№ 8. C. 327-336.

\title{
ORTHODOX MISSIONARY IN INTERFAITH INTERACTION IN THE SOUTH OF WESTERN SIBERIA IN THE SECOND THIRD OF XIX - BEGINNING OF XX CENTURY
}

\section{(C) 2019}

Nasonov Alexandr Alexandrovich, candidate of historical sciences, associate professor of Museology Department Kemerovo State Institute of Culture (Kemerovo, Russian Federation)

Abstract. The paper considers the problems of the Christian doctrine spread in the context of incorporation into Russia and the cultural development of the Siberian territory. The object of the research is the Orthodox missionary; the subject is the specifics of the missionary activity of Orthodox adepts in interfaith relations and contradictions. The author sets a goal to determine the role of Orthodox missionary in interfaith interaction in the south of Western Siberia in the second third of XIX - beginning of XX century. The paper focuses on the traditional and innovative tactical methods of improving preaching, which was transformed under the influence of changes in the state course with regard to national outskirts, and the intensification of confessional rivals. In the paper on the example of changes in the religious situation at the beginning of the XX century the author characterizes reaction of the Altai spiritual missioners to the public manifestation of the Burkhanist movement, which was a regional syncretic variation of Northern Buddhism. The author concludes that as a result of its purposeful activity, Orthodox missionary actualized the ideas of monotheism and messianism in the traditional religious consciousness of the indigenous people, but they were more successfully interpreted by Buddhist adepts in the dogma of Burkhanism. This fact contributed to the transition of missionary work from predominantly flexible methods of Christianization and to more hard and intensive methods of dogma spreading.

Keywords: interfaith interaction; Orthodox Christianity; missionary; acculturation; Christianization; messianism; proselytism; stereotype; religious syncretism; animism; shamanism; Burkhanism; Buddhism; Islam; national outskirt; Siberian indigenous people; Altai spiritual mission; south of Western Siberia.

УДК 93 / 94

DOI 10.24411/2309-4370-2019-11208

Статья поступила в редакцию 29.11.2018

\section{БРАТАНИЕ В 8-Й АРМИИ ЮГО-ЗАПАДНОГО ФРОНТА В МАРТЕ - АВГУСТЕ 1917 ГОДА} (C) 2019

\author{
Курицын Сергей Владимирович, аспирант Центра военной истории России \\ Институт российской истории РАН (г. Москва, Российская Федераџия)
}

Аннотащия. В настоящей статье сделана попытка исследовать специфику братания в одной из самых боеспособных армий Восточноевропейского ТВД периода Первой мировой войны - 8-й армии Юго-Западного фронта. Избрание указанных хронологических рамок - весна-лето 1917 г. - было обусловлено тем, что именно в этот период братание и близкие к нему формы контактов военнослужащих противоборствующих армий получили небывало широкое распространение на Русском фронте в целом и в 8-й армии в частности. Это было связано с тем, что после падения монархии в России солдатские массы желали прекращения войны. Также всплеск братания на фронте стал возможен вследствие ослабления власти командного состава в условиях революции. В статье приведены факты заинтересованности австро-германской стороны в развитии братания, а также описаны меры, принимаемые командованием российской армии и солдатскими комитетами с целью прекращения братания. Следует отметить, что для большинства русских солдат участие в братании представляло интерес во многом потому, что позволяло осуществлять меновую торговлю с военнослужащими войск Четверного союза, которые в ходе братания имели возможность получить хлеб взамен на какие-либо вещи или алкоголь. 
Ключевые слова: Первая мировая война; Восточноевропейский ТВД; Юго-Западный фронт; 8-я армия; корпус; дивизия; полк; контакты с противником; братание; посылка парламентёров; Февральская революция; разложение армии; пропаганда; сепаратный мир; прокламации; газеты; разведка; меновая торговля; алкоголь.

В данной статье сделана попытка исследовать развитие братания и близких к нему форм контактов, имевших место на участке 8-й армии Юго-Западного фронта в первые месяцы после падения монархии в России. Для достижения обозначенной цели необходимо решить следующие задачи: 1) выявить особенности братания и близких к нему форм контактов на фронте 8-й армии; 2) установить причины нарастания и затухания братания на протяжении весны - лета 1917 г.; 3) исследовать мероприятия командного состава армии и солдатских комитетов, направленных на борьбу с братанием, а также степень их эффективности.

Переходя к анализу степени изученности рассматриваемого вида антивоенных выступлений, необходимо отметить, что до настоящего времени не существует труда, полностью посвящённого исследованию братания. Однако данному феномену уделялось внимание во многих работах. Следует отметить, что о братании на фронте стали писать практически сразу же. Так, уже в мае 1917 года вышла брошюра А. Жаркова «Германские прокламации и "братание"» [1]. В ней автор выражал негативное отношение к контактам с врагом, называя братания и немецкие прокламации «новым оружием германцев» [1, с. 4]. Также летом 1917 года в Москве была издана работа П.Д. Бурского «Братание с врагом» [2]. Стоит отметить, что в названных брошюрах авторы приводят большое количество источников по теме в частности, прокламаций немцев, писем, решений войсковых комитетов.

Уделил внимание братанию в своей книге «Социалисты во Второй русской революции» и А.С. Изгоев (Ланде) [3]. Автор привёл выдержки из газет различных социалистических партий, а также из «Известий Петроградского Совета рабочих и солдатских депутатов», касающиеся братания. С его точки зрения, развитию братания способствовали не только большевики, но и другие социалистические партии, участники конференции в Циммервальде (1915 г.) и последующих конференций социалистов [3, с. 12].

В советской историографии братание также рассматривалось исследователями. Так, упоминал о братаниях в своей книге В.И. Вегер [4, с. 21]. Затем вышли работы В. Хохлова $[5$, с. $10,11,13]$, Я.Г. Тёмкина [6], Л.И. Велигуры [7; 8]. Отдельно следует выделить исследование А.Г. Ткачука, изучавшего братание на Юго-Западном и Румынском фронтах [9]. Особо выделяется статья В.В. Кутузова [10], в которой рассмотрена источниковая база, необходимая для изучения братания. Также данные о количестве случаев братаний на Русском фронте, хотя и далеко неполные, приведены в фундаментальном труде И.И. Минца [11, с. 745]. Уделил внимание изучению данной проблематики и М.С. Френкин [12, с. 12,14 , 17, 19, 28-30, 100, 157, 173-177, 273-275]. Ещё одна работа, в которой достаточно подробно рассмотрены антивоенные выступления солдат, но только на Румынском фронте, в том числе и братания, принадлежит Е.Н. Истрати [13, с. 26-119].

В постсоветский период появились новые более многоплановые исследования братания. Среди них Самарский научный вестник. 2019. Т. 8, № 1 (26) необходимо назвать монография Ю.Г. Фельштинского [14], статьи С.Н. Базанова [15-17], А.Б. Асташова [18; 19], Ю.А. Бахурина [20], В.В. Бондаренко [21]. Среди работ иностранных исследователей стоит упомянуть монографию М. Гильберта [22].

Произошедшая в России Февральская революция оказала сильнейшее влияние на обстановку на Восточном (Русском) фронте. Согласно свидетельствам перебежчиков и пленных, она вызвала в австрогерманских войсках подъём боевого духа и стремление к достижению победы. Так, согласно разведывательной сводке от 30 марта «пленный 18[-го] егер[ского] батальона 30 [-й] пех[отной] дивизии, захваченный [в] районе р. Гропенец, что около 4 вёр[ст] [к] юго-востоку [от] Пантирперев ... опрошенный [в] штарм (итаб армии. - С.К.) ... дополнил, что до переворота [в] России настроение было подавленное и ждали какого угодно мира, но узнав [о] событиях [в] России и, в частности, [в] армии, воспрянули духом и решили добиться успехов» [23, л. 81-82; 24, л. 116]. А в разведывательной сводке № 723 от 31 марта утверждалось: «Германцы [в] последнее время много говорят [о] наших внутренних событиях и уверяют, что им хорошо известно, что наши солдаты теперь не хотят воевать» [23, л. 84]. По-видимому, подобное восприятие революции в России во многом исходило от австро-германского командования. К примеру, Э. Людендорф в этой связи отмечал: «... революция наступила, и наступила внезапно. Огромная тяжесть свалилась с моих плеч. ... Наше общее положение значительно улучшилось» $[25$, с. $370-371]$.

Необходимо отметить, что уже в первые дни после падения монархии в России отмечаются попытки братания на участке 8-й армии. К примеру, в разведывательной сводке штаба 8-й армии № 516 от 5 марта сообщалось: «На некоторых участках противник разбрасывал прокламации и выставлял плакаты [c] надписями, относящимися [к] текущим событиям, [в] частности, [на] некоторых участках 200 пех[отной] герм[анской] дивизии немцы предлагали газеты и просили хлеба» [26, л. 283]. А 9 марта имел место следующий эпизод: «[В] Кирлибабском районе [на] некоторых участках наши разведчики [при] приближении к заграждениям противника слышали громкие крики: "Капут Вильгельму"» [26, л. 289]. По всей видимости, этот случай следует расценивать как умышленную провокацию, целью которой являлось установление контакта с русскими солдатами, поскольку сходные приёмы применялись войсками Центральных империй и на других фронтах [27, ч. 1, л. 83].

Лаконичные сообщения, относящиеся к 1718 марта, с определённой долей вероятности также можно считать попытками к братанию, хотя и однозначно утверждать это не позволяют источники. Так, в разведывательной сводке от 17 марта сообщалось: «[В] Кэрэшмезском районе [на] участке выс[оты] 1634 и 1723 - 10 вёр[ст] [к] югу [от] Рафаилова [в] течение всего дня наблюдалось движение небольших групп противника, [в] районе выс[оты] 952, что [в] 5 вер[стах] [к] западу [от] Ворохта, противник пытался подойти [к] выдвинутым нашим окопам» [26, л. 307]. 
Данное сообщение дополняется сводкой за 18 марта, согласно которой «... [В] районе выс[оты] 952 захвачен австриец 29[-го] полка 34[-й] пех[отной] див[изии]» [26, л. 308]. Тот факт, что сводка не содержит информации, при каких обстоятельствах был взят в плен солдат австро-венгерской армии, позволяет, с учётом предшествующего сообщения, предположить, что это могло произойти в ходе попытки к братанию. Этими случаями ограничивается перечень сообщений штаба командующего 8-й армии о братании в марте. В материалах же Штаба главнокомандующего армиями Юго-Западного фронта эти факты вовсе не получили отражения.

В апреле число случаев братаний в 8-й армии заметно возросло. Всплеск их числа имел место 2 апреля: «На первый день Пасхи почти на всём фронте армии, несмотря на строгое запрещение, происходило братание наших солдат с германцами и австрийцами» $[28$, л. 188 об.]. Следует отметить, что в день Святой Пасхи инициатива к братанию была обоюдной. Русские солдаты посещали австро-германские окопы. После Пасхи в течение первой половине апреля наблюдалось установление «... дружественных отношений между нашими войсками и противником» [28, л. 189]. И, хотя большинство русских солдат возвращалось в своё расположение, имели место и случаи задержания и взятия их в плен войсками Четверного союза. Так, в разведывательной сводке от 11 мая сообщалось: «За истекшие сутки принято [в] районе Прутчик / 7 вёр[ст] сев[ернее] Кэрэшмезэ / два наших солдата, бежавших [из] плена и задержанных противником 2 апреля [во] время братания» [29, л. 260].

Также случаи братания и близких к нему по форме контактов фиксировались командованием в районе высоты 1477, в 10 верстах к юго-западу от Томнатик, в районе высоты 1129 , расположенной северовосточнее Керешмезе (3 апреля) [23, л. 92]; в районе высоты 1064, находящейся северо-восточнее Керешмезе, а также в районе реки Валеа Стырей, к юговостоку от Кирлибаба (4 апреля) [23, л. 100]; на фронте 23-го армейского корпуса (8 апреля дважды $[27$, ч. 1, л. 72$]$ и 10 апреля [23, л. 119]); к юго-западу от Томнатик (11 апреля) [24, л. 175-176]; в долине реки Форешек, что к юго-востоку от Керешмезе (13 апреля) [24, л. 183]; на разных участках Керешмезского района, а также у высоты 952 Погарек, что к западу от Ворохта (14 апреля) [23, л. 127-129]; на участке 11-го армейского корпуса (16 апреля) [27, ч. 1, л. 143]; в районе высоты 1477, расположенной к юго-западу от Томнатик и у высоты 1554 , западнее Томнатик (23 апреля) [24, л. 237]; на высоте 1483, к западу от Капулу (24 апреля) [23, л. 147]; к югозападу от Баранова (27 апреля) [23, л. 153]; в районе Пневе (28 апреля) [23, л. 155]. Необходимо отметить, что из приведённого перечня эпизодов в оперативных и разведывательных сводках Штаба главнокомандующего армиями Юго-Западного фронта зафиксировано только пять сообщений о братании в 8-й армии за апрель 1917 г., а именно эпизоды 11, 13, 14, 16 и 23 апреля. Это, безусловно, указывает на неполноту данных, которые поступали в штаб фронта по данному вопросу.

Эти часто весьма краткие официальные сообщения дополняют свидетельства участников событий. Так, согласно воспоминаниям председателя солдат- ского комитета 660-го пехотного Черновицкого полка (165-я пехотная дивизия, 11-й армейский корпус) М.И. Секачёва, в апреле имело место братание в 660м пехотном Черновицком полку, распространившееся и на 43-й пехотный Охотский полк (11-я пехотная дивизия, 11-й армейский корпус) [30, с. 213-214].

Необходимо отметить, что австро-германская сторона использовала различные способы для провоцирования братания. Помимо белых флагов и повязок на рукавах, имели место и иные приёмы. А поскольку, как отмечалось выше, стремление к миру русских солдат довольно быстро стало известно командованию войск Четверного союза, то именно его чаще всего и использовали австрийские и германские военнослужащие. Так, «... [на] выс[оте] 1064, что 8 вёр[ст] северо-восточнее Керешмезэ, немцы кричали [из] окопов, что [в] апреле Германия и Австрия предложат России мир» [23, л. 100]. А в разведывательной сводке за 11 апреля сообщалось: «...[на] участке 1[-го] грен[адерского] полка 1[-й] пех[отной] див[изии] (выс[ота] 1477 и Рыпеци, что 11 вёр[ст] [к] юго-западу Томнатик) был выброшен белый флаг с надписью "Мир"» [23, л. 121].

Ещё один примечательный эпизод зафиксирован в разведывательной сводке от 27 апреля: «... на выс[оте] 1477 / 9 вёр[ст] [к] юго-западу [от] Баранова / [на] участке 43 герм[анского] п[олка] 1 п[ехотной] див[изии] играл оркестр, причём группы германцев пытались подойти [к] нашим окопам» [23, л. 153]. Подобные случаи были не единичны. К примеру, в начале мая при обходе передовых позиций генерал от инфантерии Л.Г. Корнилов «... был встречен... бравурным маршем германского егерского полка, к оркестру которого потянулись наши «братальщики» - солдаты» [31, с. 279]. Музыкальное сопровождение, по моему мнению, должно было создать ощущение мирной обстановки и тем самым облегчить возможность организовать братание.

В мае число эпизодов братания в 8-й армии несколько уменьшилось. В оперативных сводках Штаба главнокомандующего армиями Юго-Западного фронта получил отражение только один эпизод, и то не братания как такового, а скорее провокации, направленной, вероятно, либо на установление контактов с русскими солдатами, либо на завоевание их доверия. Так, в оперативной сводке № 2170 за 28 мая сообщалось: «... [B] VIII армии [в] 18[-м армейском] корпусе на участке восточнее Кирлибаба австрийцы кричали: «Приехали немцы пускать газы», после чего противником на бруствер был выброшен горючий предмет, давший много дыма, горение продолжалось несколько минут» [32, ч. 1 , л. 149]. Эти сведения дополняются данными разведывательного отделения Штаба командующего 8-й армией, согласно которым братание или попытки к нему, а также близкие формы контактов фиксировались в районе Керешмезского шоссе (2 мая); вероятно, попытки к братанию отмечались в Кирлибабском районе (3 мая); в районе высоты 1079, к северу от Керешмезе, а также на участке действия 11-го резервного германского полка (5 мая); в районе долины рек Рафаилов, Площанец и Прутчи, к северу от Керешмезе, а также на Керешмезском шоссе (7 мая); в районе ур. Яшевник, к северо-востоку от Керешмезе (12 мая); у высоты 980, севернее Керешмезе (21 мая); неподалёку от высоты 1042 Сумарен, северо-восточнее Керешмезе (22 мая); 
в районе высоты 1035 , к северу от Керешмезе (26 мая) [29, л. 237, 250, 252, 254, 261, 280, 281, 286].

О том, что братание в 8-й армии в мае было достаточно распространённым явлением, свидетельствует также и приведённый А.И. Деникиным эпизод, относящийся к началу мая, записанный на тот момент капитаном Генерального штаба М.О. Неженцевым: «Мы вошли в систему укреплений, где линии окопов обеих сторон разделялись, или, вернее сказать, были связаны проволочными заграждениями. Появление генерала Корнилова было приветствуемо... группой германских офицеров, нагло рассматривавших командующего русской армией; за ними стояло несколько прусских солдат. Генерал взял у меня бинокль и, выйдя на бруствер, начал рассматривать район будущих боевых столкновений. На чьёто замечание, как бы пруссаки не застрелили русского командующего, последний ответил: "Я был бы бесконечно счастлив - быть может, хоть это отрезвило бы наших затуманенных солдат и прервало постыдное братание"» [31, с. 278-279].

Необходимо отдельно остановиться на характере братания и близких к нему контактов, имевших место на фронте 8-й армии. Следует отметить, что определённая часть эпизодов братания оставалась стихийной. Так, к примеру, в разведывательной сводке от 24 апреля сообщалось: «... на выс[оте] 1483 / [в] 8 вер[стах] [к] западу [от] Капулу / участок 1[-го] грен[адерского] полка / партия противника, выкинув белый флаг, вышла [из] окопов, направляясь [к] нашей позиции, но, будучи обстреляна своими пулемётами, вернулась» [23, л. 147]. Однако весной 1917 г. данных о том, что австро-германские войска препятствовали братанию немного. Скорее имела место обратная тенденция. В этой связи интересна выдержка из приказа, касающегося борьбы с перебежчиками, но вполне применимого и к ситуациям стихийного братания. В частности, в пункте приказа по 5-му стрелковому полку к пункту приказа по 30-й австрийской пехотной дивизии за 21 октября 1916 г. говорилось: «... Без офицера ни одному солдату нельзя перейти линию проволочных заграждений. Часовым и постам стрелять в каждого, пытающегося оставить линию и уйти в сторону неприятеля в отсутствии офицера. Имена таковых часовых сообщать в штаб дивизии с целью выдачи им денежной награды и представлять их к боевой награде. Каждый захваченный беглец будет немедленно предан смертной казни» [29, л. 245 об.-246].

В марте - мае 1917 г. многие перебежчики и пленные утверждали, что братание санкционировано австро-германским командованием. Так, 3 апреля сообщалось: «[В] районе выс[оты] 1129 /что 8 вёр[ст] северо-восточнее Керешмезе/ взято 2 австрийца 32[го] пех[отного] п[олка], [при] предварительном опросе показавшие, что они $14[-$-й] роты и принадле-

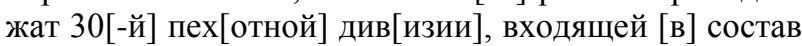
25 [-го] рез[ервного] корпуса ... захваченные прибыли в качестве депутатов [по] приказанию командира роты [с] целью братания» [23, л. 92-93].

Несколько позже, при дополнительном опросе, данные военнопленные показали: «1 апреля был прочитан приказ по 7[-й] армии, что [по] полученным сведениям [от] русских войск ожидается депутация [в] числе 6 человек [для] мирных переговоров, [во] время которых позиции не усиливать, огня не открывать, [o] прибытии депутатов известить дежур- ного офицера, нижним чинам [в] разговор [с] депутатами не вступать» [23, л. 102]. В этих показаниях примечательны два положения. Во-первых, строгий запрет на общение рядового состава австро-венгерских войск с русскими делегатами, появление которых ожидалось. Это, по нашему мнению, было обусловлено стремлением оградить австрийскую армию от разлагающего влияния со стороны русских солдат. Во-вторых, австро-германское командование, желая показать стремление к миру и тем усилить антивоенные настроения в рядах российской армии, отдавало приказы не стрелять [23, л. 107, 125]. В этой связи примечательно сообщение пленных 16-го егерского батальона, согласно которому «... запрещено стрелять [в] русских под страхом ареста» [29, л. 254]. Следствием этого стало положение на ряде участков фронта 8-й армии, когда «... противник держится подозрительно, местами совершенно не стреляет и не отвечает [на] огонь нашей артиллерии, позволяет открыто ходить и работать в окопах» [23, л. 128-129]. Интересно, что австро-германские войска не только довольно часто не открывали даже ответный огонь по позициям русской армии, но подчас не препятствовали и действиям, имевшим тактическое значение. К примеру, «... был случай, что наш офицер ввиду часовых противника [в] 300 шагах [от] его окопов произвёл съёмку местности» [29, л. 243]. Подобная тишина на фронте безусловно благоприятствовала братанию.

Ещё один эпизод, свидетельствующий о том, что австро-германские офицеры поощряли братание, зафиксирован 13 апреля, когда в долине р. Форешек, к юго-востоку от Керешмезе в плен было взято два немца 22-го резервного полка 117-й пехотной дивизии: «... пленные имели белые повязки [на] рукавах и объяснили, что вышли [со] своим командиром роты, дабы сговориться [об] обмене газет и писем офицер, оставшийся у заграждений, [при] приближении наших разведчиков скрылся» [23, л. 125].

Стоит обратить внимание и на то, что командование армий Четверного союза после всплеска братания в конце марта - начале апреля, когда вступление в контакт с русскими солдатами чаще всего им поощрялось, затем издало, по-видимому, несколько приказов, направленных на ограничение братания на фронте 8-й армии. В этой связи 7 апреля «... перебежчик 101 п[ехотного] п[олка] 34[-й] пех[отной] див[изии]... [на] предварительном опросе показал ... приказано было мешать дальнейшему братанию [c] русскими - [во] время пасхального братания, [по] показаниям перебежчика, русские говорили австрийцам [о] скором мире, решении [и] не наступать и не пускать [к] себе противника» [23, л. 111-112]. Появление подобных приказов свидетельствует о том, что австро-германское начальство уже весной 1917 г. могло влиять на динамику развития братания. Если оно считало полученные сведения о состоянии русских войск достаточными, то санкционировало уменьшение степени интенсивности контактов с русскими солдатами. Однако полного запрета контактов с русской армией всё же не последовало. По-видимому, «мешать» следовало в тех случаях, когда инициатива к братанию исходила от русской стороны и могла показаться командованию войск Австро-Венгрии и Германии чрезмерной на тех или иных участках фронта. 
Что касается целей как братания, так и близких к ним форм контактов, то, по свидетельству самих делегатов, они сводились к следующему: «На агентурном опросе [в] штарм (штаб армии. - С.К.) большинство «делегатов» показало, что цель высылки их - разложение русской армии и разведка всего, что только можно узнать у русских, главнейшее же: $1 /$ детальное ознакомление с характером укреплений, 2 / выяснение расположения пулемётов и орудий ближнего боя, 3 / номера наших войсковых частей, количество штыков 4 / настроение армии и т.д.» [29, л. 243-243 об.]. Кроме того, «многие делегаты снабжаются фотографическими аппаратами, будто бы для производства снимков, запечатлевающих братание сторон, в действительности ... для более верного запечатления наших позиций. По словам одного «делегата», австрийцам удалось произвести большое количество снимков, которые обработаны в соответствующих штабах» [29, л. 243 об.].

Особое внимание обращают на себя показания длительное время служившего в разведывательном отделении при штабе 3-й австро-венгерской армии серба, зафиксированные в сводке № 1403 от 19 июня, согласно которым «во все корпуса и дивизии разосланы разведывательные группы, состоящие из людей со специальною подготовкою для производства разведок под видом братания. По поводу братаний был приказ австрийским армиям, [в] котором первою задачею [на] русском фронте поставлено братание и пропаганда сепаратного мира, чтобы возможно дольше задержать русское наступление» [29, л. 347]. Таким образом, можно заключить, что работа, направленная на организацию братания и близких к нему форм контактов, используемых командованием Центральных держав в целях разведки и пропаганды, носила системный характер.

Необходимо сказать и о том, что уже в весенние месяцы 1917 г. во время братания употреблялись алкогольные напитки. Лаконичные сведения разведывательной сводки от 21 мая сообщает: «[В] районе выс[оты] 980 / 8 вёр[ст] сев[ернее] Кэрэшмезэ / вышел офицер при 2-х солдатах [c] газетами и ромом, удалось задержать солдата, принадлежность части коего ещё не установлена» [29, л. 280]. А 22 мая «[В] районе выс[оты] 1042 Сумарен / 7 вёр[ст] [к] сев[еро]-востоку [от] Кэрэшмезэ / группа австрийцев, вышедшая [из] окопов [с] белым флагом, прокламациями и бутылками вина, была загнана обратно нашей артиллерией» $[29$, л. 281]. Также бежавший из плена русский солдат, принятый 19 мая в Шибенском районе, сообщил: «... [во] время братания германцами 17[-го] егер[ского] б[атальона] 200 п[ехотной] див[изии] был заманен [в] окопы и угощён водкой, после чего арестован герм[анским] офицером и направлен [в] высшие штабы / до Штарм /, где, напаивая водкой, расспрашивали главным образом [o] количестве и калибре орудий нашей артиллерии. Из Штарм отправлен обратно, и позицию противника прошёл [с] завязанными глазами» [29, л. 281]. Исходя из этого, можно заключить, что снабжение русских солдат алкоголем имело двоякую цель: с одной стороны, стимулировать их участие в братании, с другой - способствовать более непринуждённому общению, «развязать язык» с целью выяснения военных секретов.
Отдельно следует сказать, что, помимо братаний, на фронте 8-й армии имела место и несколько иная форма контактов - посылка парламентёров от австро-германских войск. Необходимо отметить, что из приведённого выше перечня эпизодов, имевших место в апреле, посылка парламентёров зафиксирована только в следующих случаях: у высоты 952 Погарек, что к западу от Ворохта (14 апреля) [24, л. 188-189]; у высоты 1554, западнее Томнатик (23 апреля) [24, л. 237]; на высоте 1483, в районе Пневе (28 апреля) [23, л. 155]. Призывы же прислать парламентёров или встретиться с делегатами от войск Центральных держав отмечались на фронте 23-го армейского корпуса, где приглашались парламентёры от российской стороны (10 апреля) [23, л. 119]; на фронте 18 армейского корпуса (23 апреля) [33, с. 162]. Такого рода призывы содержались и в иных прокламациях [33, c. 166-167].

В мае же число случаев посылки парламентёров значительно возросло, хотя и общее количество контактов в целом сократилось. Если исходить из материалов Штаба командующего 8-й армией, то на её фронте в мае вместо классического братания получила распространение именно посылка парламентёров. Так, из перечня эпизодов, зафиксированных в мае, данный вид контактов имел место в районе Керешмезского шоссе (2 мая); в районе высоты 1079 , к северу от Керешмезе, а также на участке действия 11-го резервного германского полка (5 мая); в районе долины рек Рафаилов, Площанец и Прутчи, к северу от Керешмезе, а также на Керешмезском шоссе (7 мая) [29, л. 237, 252, 254].

Теперь следует более подробно рассмотреть некоторые факты посылки парламентёров. В этой связи заслуживает внимания эпизод, произошедший 14 апреля: «К выс[оте] 952 Погарек / что 5 вёр[ст] [к] западу Ворохта / (по-видимому против стыка 11[-го] герм[анского] п[олка] с 101[-ым] п[ехотным] п[олком] 34[-й] пех[отной] див[изии] или фланге последнего) вышел австрийский офицер с трубачом и солдатом, несшим белый флаг. Трубач подал сигнал, и [c] нашей стороны был выслан офицер при двух солдатах» [23, л. 127-128]. Глава австро-венгерской делегации заявил: «... претензии [за] стрельбу нашей артиллерии даже [по] мелким партиям, не свыше 3 человек, тогда как наша (австро-венгерская. C.K.) артиллерия не стреляет [по] работающим днём» [23, л. 128]. В этой связи необходимо отметить, что призывы, обращённые к пехоте, повлиять на артиллеристов или даже применить к ним силу неоднократно звучали как в австро-венгерских [33, c. $158-159,171]$, так и в немецких [33, с. 165-166, 172-173, 239] прокламациях в апреле-мае 1917 г.

Также австрийский офицер заявил, что уполномочен «... передать решение своей дивизии [на] нашем фронте не наступать и не допускать другие войска» $[23$, л. 128$]$. По нашему мнению, эти слова имели целью создать у русских солдат ложное впечатление о состоянии австро-венгерской армии, которое, исходя из подобного обещания, было сходно с состоянием русских войск, а также усыпить их бдительность. В этой связи следует сказать, что, хотя и вооружённые силы Австро-Венгрии к 1917 г. имели гораздо меньший боевой потенциал, чем германские, тем не менее принцип единоначалия, а также воз- 
можность вести наступательные операции они сохраняли до конца войны.

Целью посылки парламентёров, как и в случаях классического братания, являлось, в частности, стимулирование в массе русских солдат антивоенных настроений [31, с. 279-280]. На фронте 8-й армии подобный случай был зафиксирован 23 апреля: «[В] районе выс[оты] 1554 Пирие / 16 вёр[ст] [к] западу [от] Томнатик / появился парламентёр противника поручик Кайзерлинг, заявивший, что уполномочен штабом армии вести переговоры [о] перемирии, так как через 3 дня якобы Германия предложит России мир без аннексий и контрибуций. На предложение для переговоров пройти [в] штаб отказался, требуя заложника [в] чине не ниже поручика» [23, л. 145]. Обращает на себя внимание использование парламентёром сочетания «мир без аннексий и контрибуций». По-видимому, озвучивание данной формулы мира, получившей широкое распространение в российском обществе и армии после Февральской революции, имело целью максимально стимулировать антивоенные настроения русских солдат.

Ещё один подобный эпизод был зафиксирован и 28 апреля, когда «... [в] районе Пневе задержан офицер и 2 солдата 65 л[анд]шт[урменного] п[олка] 200 пех[отной] див[изии], прибывшие [для] переговоров [от] имени командира полка» [23, л. 155]. Однако в этом случае всё закончилось пленением парламентёров. Это свидетельствует о том, что солдаты на данном участке фронта армии в целом не поверили пропаганде мира германских делегатов и не воспрепятствовали их задержанию.

Схожий эпизод отмечен и в разведывательной сводке от 2 мая: «[В] районе Кэрэшмезского шоссе вышел офицер парламентёр с двумя солдатами [c] белыми повязками и трубой, офицер австриец 34 арт[иллерийского] п[олка] заявил, что послан Начдив 34 (начальник 34-й дивизии. - С.К.) [c] пакетом [для] передачи русскому Командарм (командующий арми$e \check{u} .-$ C.K.)» [29, л. 237]. Интересно, что в этот раз «... офицер был доставлен [в] штадив (штаб дивизии. C.K.), по передаче пакета парламентёры отпущены» [29, л. 237].

Примечательны и факты появления парламентёров сразу на нескольких участках фронта армии 7 мая: «[В] районе долины р.p. Рафаилов, Площанец и Прутчи / участок Пантир перев. и Выбчина / что 7 вер север Кэрэшмезэ / вышли парламентёры, по одному офицеру и 3 солдата... [В] то же время [на] Кэрэшмезском шоссе захвачено 2 офицера штадив 34 и 2 солдата 101[-го] п[ехотного] п[олка] 34[-й] п[ехотной] д[ивизии]. Последние пришли [c] пакетами агитационного характера, адресованными комитетам наших 45[-го пехотного Азовского генералфельдмаршала Головина] и 46[-го пехотного Днепровского] полков (оба полка в составе 12-й пехотной дивизии, 11-го армейского корпуса. - С.К.)» [29, л. 254]. Следует отметить, что в итоге «...парламентёры первых двух групп взяты [в] плен» [29, л. 254]. У делегатов, взятых в плен в районе реки Площанец и принадлежавших к штабу 30 австрийской дивизии, имелись «... 4 пакета одинакового воззвания [к] полковому комитету 659[-го пехотного Буковинского] полка (165-я пехотная дивизия, 11-й армейский кор$n y c$. - C.K.) о немедленном установлении перемирия» [29, л. 260].
Нельзя также не сказать об эпизоде, по своему характеру занимающему промежуточное положение между такими формами контактов, как посылка парламентёров и братание: 5 мая «...[В] районе действия 11[-го] резервного [германского] полка захвачено 2 германца этого полка, показавшие, что пришли [с] письмом, которое им передал их батальонный командир. Это ответ нашим солдатам [на] письмо, переданное ими накануне герман[скому] офицеру» [29, л. 252]. Этот факт позволяет сказать, что различные формы контактов могли переходить одна в другую, в зависимости от обстановки. Кроме того, данный эпизод показывает, что представители австро-германского командного состава были готовы вступать в диалог не только с офицерами и комитетами русской армии, но и с группами солдат, очевидно, с целью внесения в их среду своей пропаганды.

Заслуживает также отдельного рассмотрения вопрос о том, какие меры принимались командным составом и комитетами для борьбы с братанием. Как и в других армиях Юго-Западного фронта, офицеры и комитеты всех уровней разъясняли солдатам пагубность братания для дела обороны. Если же братание всё же начиналось, то отдавались приказы открывать по участку, на котором оно происходило, огонь. Чаще всего братание прекращали залпы лёгкой артиллерии. Кроме того, необходимо отметить, что довольно часто братание на фронте 8-й армии заканчивалось взятием в плен австро-германских представителей. Интересно, что из приведённого перечня фактов, зафиксированных в апреле, по крайней мере в шести случаях братание заканчивалось взятием в плен военнослужащих Центральных империй. К примеру, 3 апреля были задержаны два австрийца 32-го пехотного полка 30-й пехотной дивизии [23, л. 92-93], а 4 апреля «[в] районе р. Валеа Стырей / что [в] 6 вер[стах] [к] юго-востоку [от] Кирлибаба / задержано 6 венгров 5 гус[арского] п[олка], пришедших [c] поздравлениями» [23, л. 101]. Примечательно также то, что эти случаи, произошедшие в пасхальные дни, тем не менее не вызвали, повидимому, сопротивления со стороны солдат. А эпизод с захватом немецких братальщиков в плен имел место 13 апреля: «[В] долине р. Форешек, что [в] 8 вер[стах] [к] юго-востоку [от] Кэрэшмезэ, захвачено 2 германца 22[-го] рез[ервного] п[олка] 117[-й] пех[отной] див[изии], пришедшие [для] переговоров [c] нашими солдатами» [23, л. 125]. Также немецких военнослужащих удалось захватить в плен во время братания 23 и 28 апреля [23, л. 145, 155]. Особого внимания заслуживает эпизод несостоявшегося братания, имевший место на фронте 11-го армейского корпуса 16 апреля, когда «...засада разведчиков 47[го пехотного Украинского] полка атаковала партию германцев, вышедших из своих окопов, захватив одного [в] плен, остальные бежали» [27, ч. 1, л. 143].

Следует сказать, что, по всей видимости, перечисленные эпизоды захвата в плен австро-германских делегатов имели место и в других соединениях 8-й армии. Об этом свидетельствуют, в частности, действия представителей армий Четверного союза. К примеру, в упомянутом выше эпизоде, имевшем место 14 апреля в районе высоты 952, к западу от Ворохта вышедший австрийский офицер с трубачом и солдатом кроме прочего заявил: «Уполномочен ди- 
визией ... спросить причину задержания вами раньше 4 человек» [23, л. 128]. А в прокламации, обнаруженной на участке 18-го армейского корпуса 25 апреля, говорилось: «Так как Вы вчера задержали трёх людей, которые хотели Вам принести газеты до заграждения, где Вы их могли бы получить, мы сегодня обстреливали каждого являющегося русского. Заботьтесь о том, чтобы эти три люди (так в докумен$m e .-C . K$.$) нам были бы возвращены» [33, с. 163].$

В течение мая количество случаев пленения австро-германских братальщиков возросло, хотя и общее число эпизодов братания и близких к нему форм контактов, а также попыток к ним в целом сократилось. Взятие в плен военнослужащих Четверного союза (пришедших групп в полном составе или частично) имело место в районе высоты 1079 , к северу от Керешмезе, а также на участке действия 11-го резервного германского полка (5 мая); в районе долины рек Рафаилов и Площанец, к северу от Керешмезе, а также на Керешмезском шоссе (7 мая); у высоты 980, севернее Кэрэшмезэ (21 мая); в районе высоты 1035, к северу от Керешмезе (26 мая) [29, л. 252, 254, 280, 286].

Приведённые факты, на наш взгляд, свидетельствуют о том, что далеко не все солдаты 8-й армии поддерживали братание даже в апреле, на который пришёлся пик распространения этого вида антивоенных выступлений как в рассматриваемой армии, так и на Юго-Западном фронте в целом. Иначе захвату в плен пришедших с целью братания австро-германских военнослужащих было бы оказано противодействие солдатской массы. И хотя далеко не всегда братание заканчивалось взятием в плен австрийцев и немцев, тем не менее в 8-й армии количество такого рода фактов составляет практически 1/3 от приведённого перечня эпизодов братаний, зафиксированных в апреле и более половины - в мае, по данным Штаба командующего 8-й армией и главнокомандующего армиями Юго-Западного фронта.

Необходимо сказать особо об основных мерах, которые были разработаны генералом от инфантерии Л.Г. Корниловым для борьбы с братанием. Лавр Георгиевич, находясь на посту командующего 8-й армией с 29 апреля по 10 июля 1917 г., сумел добиться того, что к концу мая братание на фронте армии было сведено к минимуму. В этой связи обращает на себя внимание письмо солдата 255-го пехотного Аккерманского полка (64-я пехотная дивизия, 18-й армейский корпус) в Петроградский совет, написанное не позднее 31 мая, в котором, в частности, указывалось: «Насчёт братания я скажу то, что это уже всё прекращено, и теперь этого нет» $[34$, с. 66]. Безусловно, солдат не владел всей полнотой информации о происходившем на фронте 8-й армии. Однако данные сведения подтверждаются и отсутствием зафиксированных случаев братания в оперативных сводках штаба фронта за рассматриваемый месяц, а также отчётами органов военной цензуры [35, с. 124]. Вместе с тем попытки австро-германской стороны возобновить братание имели место в июне. Так, 23 июня «...[в] районе сев[еро]-вост[очнее] Шибены захвачено 2 германца без оружия, [c] прокламациями» [29, л. 359]. А 26 июня «пленный 1[-го] грен[адерского] полка $1[-и ̆]$ герм[анской] пех[отной] див[изии], взятый [в] районе 7 вёр[ст] [к] западу [от] Капуль, показал: выслан был для братания» [29, л. 363].
Отдельно следует сказать об эпизоде, зафиксированном в разведывательной сводке от 10 июня: «Во время разбрасывания прокламаций два наших разведчика / люди очень надёжные / были окружены [в] районе Ляховце / 2 вер[сты] юго-зап[аду] [от] Богородчаны / австрийцами. Последние приняли их как парламентёров и повели [с] завязанными глазами [в] штаб полка. По дороге одному [из] разведчику удалось опустить повязку, он насчитал четыре линии окопов», а также описал их состояние [29, л. 317]. Разведчики были допрошены в полку, а затем в штабе дивизии: «... Опрашивающие интересовались главным образом, будут ли русские наступать и сколько артиллерии. Разведчики отвечали, что наступать наши не собираются, артиллерии мало» [29, л. 317]. Обращает на себя внимание тот факт, что «... на следующее утро разведчики ... пропущены [в] нашу сторону [c] предложением начать опять братание и прекратить стрельбу» [29, л. 317].

Для того, чтобы во время подготовки наступления братание в 8-й армии не возобновилось в прежних масштабах Л.Г. Корнилов в своём приказе от 10 июня предписывал принять следующие меры: «Для создания тайны наших действий приказываю, чтобы на пассивных участках с первого дня артиллерийской подготовки в окопах безотлучно находились бы полковые и батальонные командиры, комитеты (подчёркнуто в документе. - C.К.), а старшие начальники лично обходили бы их не менее раза в день в сопровождении своих комитетов. Днём усилить число наблюдателей, ночью организовать непрерывное патрулирование между окопами и проволочными заграждениями, мера эта должна пресечь всякую возможность общения наших солдат с противником» $[36$, л. 229]. Данные действия оказались весьма эффективны.

В дальнейшем, находясь уже на посту Верховного главнокомандующего, Л.Г. Корнилов 1 августа издал Приказ № 748 по действующей армии, согласно которому для искоренения братания следовало: «... 1) в случае открытого братания целыми группами немедленно открывать по ним артиллерийский и пулемётный огонь; 2) при проникновении для братания неприятеля в наше расположение в плен не брать, а прикалывать пришедших на месте и трупы их выставлять впереди проволочных заграждений; 3) наших солдат за попытки к братанию предавать военно-революционному суду как за измену» [37, с. 203]. И хотя, по-видимому, эти меры так и остались декларативными, они способствовали значительному сокращению числа случаев братания.

\section{Выводы}

Таким образом, необходимо заключить, что в 8-й армии братание нарастало с конца марта до первой декады мая включительно, после чего наметилось постепенное уменьшение числа случаев братания и близких к нему видов контактов (посылки парламентёров от австро-германских войск). К началу июня в целом с братанием в 8-й армии удалось справиться, добившись его снижения до минимума.

Стоит обратить внимание и на то, что если в апреле на участке 8-й армии получило распространение классическое братание, то в мае, на фоне общего снижения интенсивности контактов, отмечается увеличение числа случаев посылки парламентёров от австро-германских войск, что, по всей вероятности, свидетельствует о том, что классическое братание на 
данном участке Юго-Западного фронта командование армий центральных держав сочло недостаточно эффективным.

Для русских же солдат одной из главных причин участвовать в братании (помимо стремления к прекращению боевых действий) являлась меновая торговля с австро-германскими военнослужащими, в ходе которой представлялась возможность получить редкие, дефицитные вещи. Следует отметить, что уже в весенние месяцы 1917 г. русские солдаты всё чаще обменивали хлеб и иное продовольствие на алкоголь. Австро-германские же представители приносили горячительные напитки на братания с целью усилить разложение русской армии. Кроме того, наличие спиртного способствовало более легкому выяснению у нетрезвых солдат мест расположения огневых точек русской армии.

Для прекращения братания командованием и комитетами принимались различные меры: разъяснение вреда братания; разоблачение перед солдатами истинных целей австро-германского командования, а именно его разведывательной деятельности в ходе братания; обстрел братающихся; захват в плен австро-германских военнослужащих, пришедших с целью братания и допрос их в штабах корпусов и Штабе армии. В особенности борьба с братанием и близкими к нему формами контактов усилилась в связи с подготовкой к июньскому наступлению. Во многом успех в борьбе с братанием стал возможным благодаря деятельности в этот период на посту командующего 8-й армией генерала Л.Г. Корнилова.

\section{Список литературы:}

1. Жарков А. Германские прокламации и «братание». Пг.: Военная типография, 1917. 15 с.

2. Бурский П.Д. Братание с врагом // Народные беседы. 1917. № 17.17 с.

3. Изгоев А.С. Социалисты во Второй русской революции. Пг.: Партия народной свободы, 1917. 84 с.

4. Вегер В.И. К изучению ленинизма. Ленин. Большевики. Диктатура пролетариата. Иваново-Вознесенск: Основа, 1924. 74 с.

5. Хохлов В. Тактические разногласия среди большевиков в 1917 г. М.: Государственное социальноэкономическое издательство, 1931. 77 с.

6. Тёмкин Я.Г. Большевики в борьбе за демократический мир. М.: Государственное издательство политической литературы, 1957. 435 с.

7. Велигура Л.И. В.И. Ленин о значении братания на русско-германском фронте в период подготовки Великой Октябрьской социалистической революции // Великий Октябрь и революционное движение в Германии. Днепропетровск, 1977. С. 28-39.

8. Велигура Л.И. К вопросу о братании на русскогерманском фронте в период борьбы Советской России за претворение в жизнь Декрета о мире (ноябрь декабрь 1917) // Вопросы германской истории. Русско-германские отношения Нового и Новейшего времени. Днепропетровск: ДГУ, 1982. С. 96-104.

9. Ткачук А.Г. Братание на фронтах в 1917 г. (по материалам Юго-Западного и Румынского фронтов) // Участие трудящихся зарубежных стран в Октябрьской революции. М.: Наука, 1967. С. 131-145.

10. Кутузов В.В. Документы о братаниях в фондах ЦГВИА // Советские архивы. 1968. № 4. С. 98-101.

11. Минц И.И. История Великого октября. В 3 т. Т. 2. М.: Наука, 1977. 1008 с.
12. Френкин М.С. Русская армия и революция. Мюнхен: Logos, 1978. 750 с.

13. Истрати Е.Н. Демократическое движение за мир на Румынском фронте в 1917 году. Кишинев: Штиинца, 1973. 148 с.

14. Фельштинский Ю. Крушение мировой революции. Брестский мир: Октябрь 1917 - ноябрь 1918. M.: TEPPA, 1992. $656 \mathrm{c}$.

15. Базанов С.Н. «Немецкие солдаты стали ... переползать к русским «товарищам» и брататься с ними» // Военно-исторический журнал. 2002. № 6 . C. $43-50$.

16. Базанов С.Н. Феномен братания на Русском фронте // Первая мировая война в истории и культуре России и Европы: сб. статей. Калининград, 2013. C. $154-162$.

17. Базанов С.Н. Братание как феномен Первой мировой войны // Первая мировая война - тропы XX века: мат-лы междунар. науч. конф. (Москва, 810 сентября 2014). Ч. 2. М., 2015. С. 215-222.

18. Асташов А.Б. Братания на Русском фронте Первой мировой войны // Новый исторический вестник. 2011. № 2. С. 29-41.

19. Асташов А.Б. Братания на Русском фронте Первой мировой войны: между пацифизмом и мировой революцией // Первая мировая война, Версальская система и современность: сб. статей. СПб., 2012. C. $40-47$.

20. Бахурин Ю.А. О первых братаниях с противником в годы Первой мировой войны // Вопросы истории. 2010. № 12. С. 167-168.

21. Бондаренко В.В. Братания на фронте // Россия в Первой мировой войне. 1914-1918. Энциклопедия. B 3 т. T. 1. М., 2014. C. 203-205.

22. Гильберг М. Первая мировая война / Пер. с англ. С. Бавина, Ю. Гольберга, П. Кунарева, А. Курт. М.: КоЛибри, Азбука-Аттикус, 2016. 768 с.

23. Российский государственный военно-исторический архив (РГВИА). Ф. 2129. Оп. 1. Д. 159.

24. РГВИА. Ф. 2129. Оп. 1. Д. 140.

25. Людендорф Э. Мои воспоминания о войне 1914-1918 гг. / Пер. с нем. А.А. Свечина. М.: Вече, 2014. 704 c.

26. РГВИА. Ф. 2134. Оп. 1. Д. 96.

27. РГВИА. Ф. 2067. Оп. 1. Д. 192.

28. РГВИА. Ф. 2134. Оп. 1. Д. 45

29. РГВИА. Ф. 2134. Оп. 1. Д. 856.

30. Секачев М.И. Курсом на революцию // Октябрь на фронте: воспоминания. М.: Воениздат, 1967. C. 212-221.

31. Деникин А.И. Очерки русской смуты. В 5 т. Т. 1. Крушение власти и армии. Февраль - сентябрь 1917. Мн.: Харнест, 2002. 464 с

32. РГВИА. Ф. 2067. Оп. 1. Д. 193.

33. Пропаганда на Русском фронте в годы Первой мировой войны / авт.-сост. А.Б. Асташов. М.: Спецкнига, 2012. 400 с.

34. Солдатские письма 1917 года / подг. к печати О.Н. Чаадаевой. М.; Л.: Госиздат, 1927. 165 с.

35. Асташов А.Б. Русский фронт в 1914 - начале 1917 года: военный опыт и современность. М.: Новый хронограф, 2014. 740 с.

36. РГВИА. Ф. 3010. Оп. 1. Д. 77.

37. Антивоенные выступления на Русском фронте в 1917 году глазами современников (воспоминания, документы, комментарии) / авт.-сост. С.Н. Базанов. М.: Институт Российской истории РАН, 2010. 363 с. 


\title{
FRATERNIZATION IN THE $8^{\text {TH }}$ ARMY OF THE SOUTH-WESTERN FRONT IN MARCH-AUGUST 1917
}

(C) 2019

\author{
Kuritsyn Sergey Vladimirovich, postgraduate student of Center for Military History of Russia \\ Institute of Russian History of Russian Academy of Sciences (Moscow, Russian Federation)
}

\begin{abstract}
This paper attempts to explore specifics of fraternization in one of the most efficient armies of the Eastern European Theater during the First World War - the $8^{\text {th }}$ army of the South-Western front. The election of this chronological framework - spring-summer 1917 - was due to the fact that it was during this period of fraternization and its close forms when soldiers of the opposing armies were unprecedentedly widespread on the Russian front in general and in the $8^{\text {th }}$ army in particular. This was due to the fact that after the fall of the monarchy in Russia, the soldiers masses wanted to put an end to the war. Fraternization at the front became possible due to the weakening of the power of the command staff in the conditions of the revolution. The paper presents the facts of the AustroGerman side interest in fraternization development, as well as the measures taken by the command of the Russian army and the soldiers' committees to stop fraternization. It should be noted that for most Russian soldiers fraternization was of great interest because it allowed them to barter with the military forces of the Quadruple Alliance, which had an opportunity to obtain bread in exchange for any things or alcohol.

Keywords: World war I; Eastern European theatre; South-Western front; $8^{\text {th }}$ army; corps; division; regiment; contacts with enemy; fraternization; sending of parliamentarians; February revolution; decomposition of army; propaganda; separate world; proclamations; Newspapers; intelligence; barter; alcohol.
\end{abstract}

\section{УДК 93/94}

DOI 10.24411/2309-4370-2019-11209

Статья поступила в редакцию 16.01.2019

\section{СУДЬБЫ КУЛЬТУРНО-ИСТОРИЧЕСКИХ ЦЕННОСТЕЙ РОССИИ НА СЛОМЕ ЭПОХ (1917-1927 ГОДЫ)}

(C) 2019

Татаренкова Наталия Андреевна, кандидат исторических наук, доцент кафедры социологии, политологии и истории Отечества Самарский государственный технический университет (г. Самара, Российская Федерация)

Аннотация. В статье рассматриваются проблемы сохранения объектов истории и культуры России в условиях 1917-1927 гг. Анализируются противоречивые процессы в культурной жизни советского государства в первое послереволюционное десятилетие. На основе архивных источников показывается деятельность отделов охраны памятников искусства и старины. На примере ряда губерний описывается проведение первой государственной описи художественно-исторических ценностей, трудности в реализации политики их охраны. Приводятся примеры разгрома дворянских усадеб. Подчеркивается роль творческой интеллигенции в спасении и музеефикации культурных ценностей. Даются характеристики ряда музейных деятелей обозначенной эпохи; подчеркивается, что они смогли в определенной степени «скорректировать» революционный нигилизм по отношению к культурному наследию, который проявлялся в деятельности новых органов власти. Указывается, что 1920-е годы стали «золотым веком» в истории музейного дела. В этот период музеи страны пополнились предметами искусства и старины из государственных и частных хранилищ. Делается вывод, что музеефикация церковных зданий и предметов богослужебного культа была способом спасти их от полной гибели. Автором вводятся в научный оборот новые материалы, почерпнутые в центральных и областных архивах Российской Федерации.

Ключевые слова: государственная опись; Государственный музейный фонд; губернский отдел народного образования; дворянская усадьба; культура; культурное наследие; музей; музейная политика; музеефикация; Отдел по делам музеев и охране памятников искусства и старины Народного комиссариата просвещения; преемственность; революционный нигилизм; художественная интеллигенция; художественные ценности.

В 1917-1927 гг. Россия переживала сложнейший период смены парадигмы общественно-политического и экономического развития, что не могло не отразиться на сфере культуры. Страна обладала богатейшим культурным наследием, судьбы которого зависели от проводимой новой властью политики по отношению к художественно-историческим ценностям, позиции интеллигенции и главного «творца» всех изменений - рабоче-крестьянских масс. Изучение этой проблемы представляет значительный научный интерес, поскольку позволяет проанализировать противоречивые процессы в культурной жизни советского государства в обозначенный период. Данная тема является актуальной, так как всегда важной остается проблема преемственности и новаций в ее развитии, отношения к памятникам истории и культуры. Формирование этого отношения закладывалось в первые послереволюционные годы.

В данном исследовании ставится цель проанализировать деятельность центральных и местных органов охраны памятников искусства и старины в 19171927 гг. На основе архивных и иных источников решаются такие задачи, как рассмотрение проведения первой государственной описи художественно-исторических ценностей, трудностей в реализации политики их охраны, роли творческой интеллигенции в спасении и музеефикации художественно-исторических ценностей. 